\title{
FIRST REPORT OF Meloidogyne incognita PARASITIZING Momordica charantia L. IN PERNAMBUCO, BRAZIL
}

Francisco Jorge Carlos Souza Junior ${ }^{1}$, Mayara Castro Assunção ${ }^{1}$, Liany Regina Bezerra de Oliveira Silva², Jaime Corbiniano Santos Neto², Arielena Augusta Rodrigues Mello²

\begin{abstract}
${ }^{1}$ Engenheiros Agrônomos, Doutorandos em Fitopatologia, Universidade Federal Rural de Pernambuco (UFRPE), Rua Dom Manuel de Medeiros, s/n, - Dois Irmãos - Recife/PE - CEP: 52171-900

2Discentes do Curso de Agronomia, Universidade Federal Rural de Pernambuco (UFRPE), Rua Dom Manuel de Medeiros, s/n, - Dois Irmãos - Recife/PE - CEP: 52171-900

*Autor para correspondência: Francisco Jorge Carlos Souza Junior, jorgesouza@alu.ufc.br
\end{abstract}

ABSTRACT: Momordica charantia roots showing symptoms of root-knot disease were collected from vegetable gardens in the city of Recife, PE, Brazil. Through morphological and enzymatic characterization and molecular analysis of ITS and 28S rDNA regions, Meloidogyne incognita was identified. This is the first report of this species in M. charantia in the state of Pernambuco, Brazil.

KEYWORDS: Root-knot nematodes, Cucurbitaceae, ribosome markers, ITS, $28 S$

\section{PRIMEIRO RELATO DE Meloidogyne incognita PARASITANDO Momordica charantia L. EM PERNAMBUCO, BRASIL}

RESUMO: Raízes de Momordica charantia apresentando sintoma de meloidoginose foram coletadas em hortas na cidade de Recife, PE, Brasil. Através da caracterização morfológica, enzimática e análise molecular das regiões ITS e $28 \mathrm{~S}$ rDNA, foi identificada Meloidogyne incognita. Este é o primeiro relato da espécie em M. charantia no estado de Pernambuco, Brasil.

PALAVRAS-CHAVE: nematoide das galhas, Cucurbitaceae, marcadores ribossômicos, ITS, 28S

Momordica charantia L. is a monoecious plant belonging to the Curcubitaceae family, popularly known in Brazil as "melão-de-São-Caetano", "fruta de cobra", "momórdica", "erva de São Vicente", "maravilha", "melãozinho", among others. It originates in eastern India and southern China, and is present in tropical areas of Asia, the Americas and in western Africa, which are hot and humid regions that provide optimal plant development, being fully adapted to Brazil (Cordeiro et al., 2010; Robinson and Decker-Walters, 1997).

In production areas, it is considered an invasive plant, as it directly competes with the main crop for nutrients, water and space, compromising development and affecting the quality of final products. This species has important metabolites such as alkaloids, steroids, saponins and triterpenes with proven pharmacological activities, such as antibacterial, anticancer, antiparasitic, anti-inflammatory, antiulcerogenic, antilipidemic, hypoglycemic, antihypertensive, among others (Coutinho et al., 2009).
The genus Meloidogyne Goeldi (1887), also known as root-knot nematode, parasites almost all plant species, mainly economically important crops and has wide geographical distribution (Moens et al., 2009). In the world ranking, it occupies the first position among nematodes harmful to agricultural crops, being also associated with alternative hosts, such as invasive plants, which act as source of inoculum, maintaining populations in areas and contributing to productivity losses (Jones et al., 2013).

In September 2019, five M. charantia root samples with symptoms of myeloidoginosis (Figure 1) were collected from vegetable gardens in the city of Recife ( $8^{\circ} 1^{\prime} 1$ 'S and $34^{\circ} 56^{\prime} 39^{\prime \prime} W$ ), in the state of Pernambuco Brazil. Roots were processed for nematode extraction according to method proposed by Coolen and D'Herde (1972) aimed at inoculation to multiply populations and later, perineal sections were made using 20 females, according to methodology of Taylor and Netscher (1974). 
Figure 1. Momordica charantia roots showing root-knot symptom by Meloidogyne incognita.

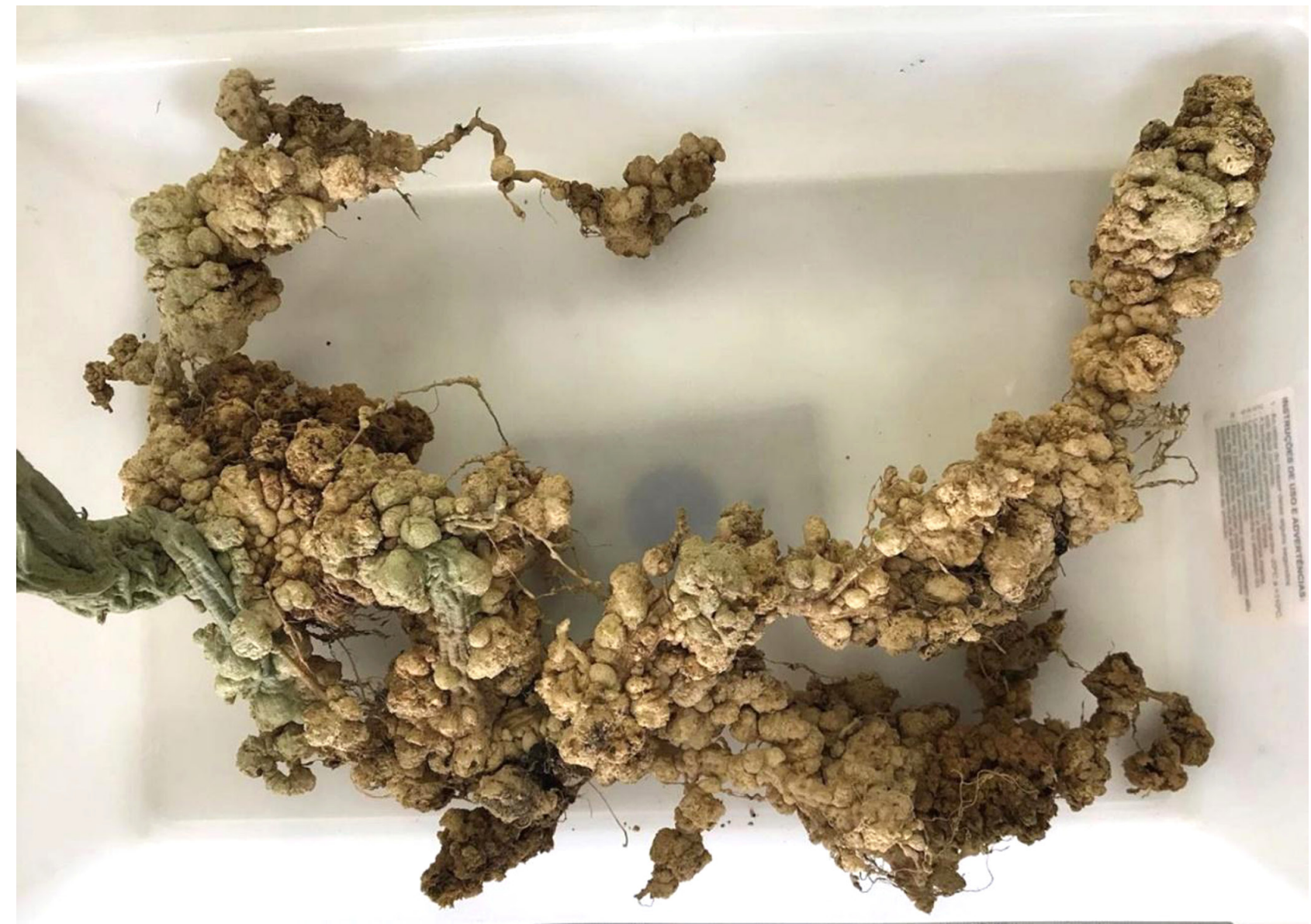

The determination of the esterase profile was made according to Carneiro and Almeida (2001), using one female per sample, with 20 replicates $(n=20)$.

Molecular identification was carried out by amplifying and sequencing D2-D3 regions of the 28S $\mathrm{rDNA}$ segment with D2A (ACAAGTACCGTGAGGGAAAGTTG) and D3B (TCGGAAGGAACCAGCTACTA) (De Ley et al., 1999) and ITS primers with VRAIN2F (CTTTGTACACACCGCCCGTCGCT) and VRAIN2R (TTTCACTCGCCGTTACTAAGGGAATC) primers (Vrain et al., 1992). Phylogenetic analysis used the Maximum likelihood (MV) methods for individual genes, performed via RAxML-HCP2 v.8.2.8 (Stamatakis, 2014) implemented in CIPRES Portal v.2.0 (https:// www.phylo.org/portal2 /home.action).

The perineal patterns of females in the $\mathrm{CNO} 021$ population showed high, square dorsal arch, with wavy streaks folded towards lateral lines and absence of distinct notches in lateral lines (Figure 2). Slides were deposited (CN0021) in the Nematological collection of the Federal Rural University of Pernambuco (UFRPE), Pernambuco, Brazil.
Figure 2. Perineal pattern of Meloidogyne incognita females found in Momordica charantia roots.

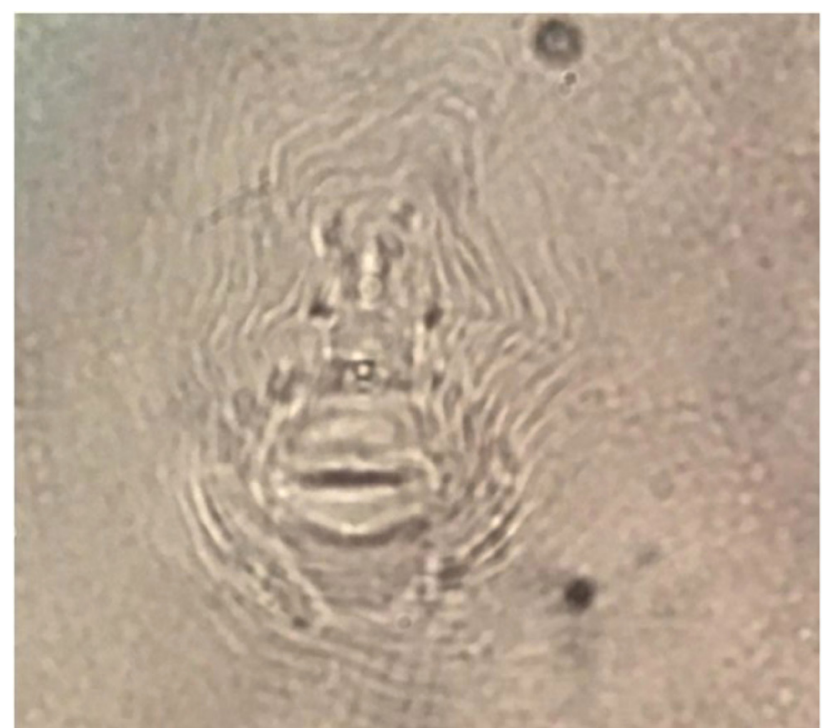

In females, body length was $430 \mu \mathrm{m}$; the style measured $12.3 \mu \mathrm{m}$ in length; the distance between the opening of the esophageal dorsal gland and the base of the basal nodules of the style (DGO) was $3.1 \mu \mathrm{m}$. For second-stage juveniles, body length was $355 \mu \mathrm{m}$; style length $10 \mu \mathrm{m}$; DGO equal to $2.4 \mu \mathrm{m}$; and tail 
measurements $c=8.99 \mu \mathrm{m}$ and tail length / body width at anus height $=4.88 \mu \mathrm{m}$.

Polymorphisms of esterasebands byelectrophoresis revealed $I 1$ phenotype $(R m$ 1.0) typical of $M$. incognita. The sequences of studied rDNA regions were submitted to GenBank (ITS: MT239111 and D2-D3 28S: MT239113).
Research on BLAST showed $98 \%$ to $97 \%$ identity with sequences of $M$. incognita isolates from Brazil, China and India. Phylogenetic analyses of these sequences, using MV, classified the Meloidogyne population (CNO021) isolated from $M$. charantia in a clade with $M$. incognita sequences from the GenBank (Figures 3 and 4).

Figure 3. Phylogenetic relationship of Meloidogyne species based on the sequential alignment of D2-D3 region of the $28 \mathrm{~S}$ rDNA segment. The phylogenetic tree was estimated by Maximum Likelihood. Pratylenchus scribneri and P. zeae were used as outgroups.

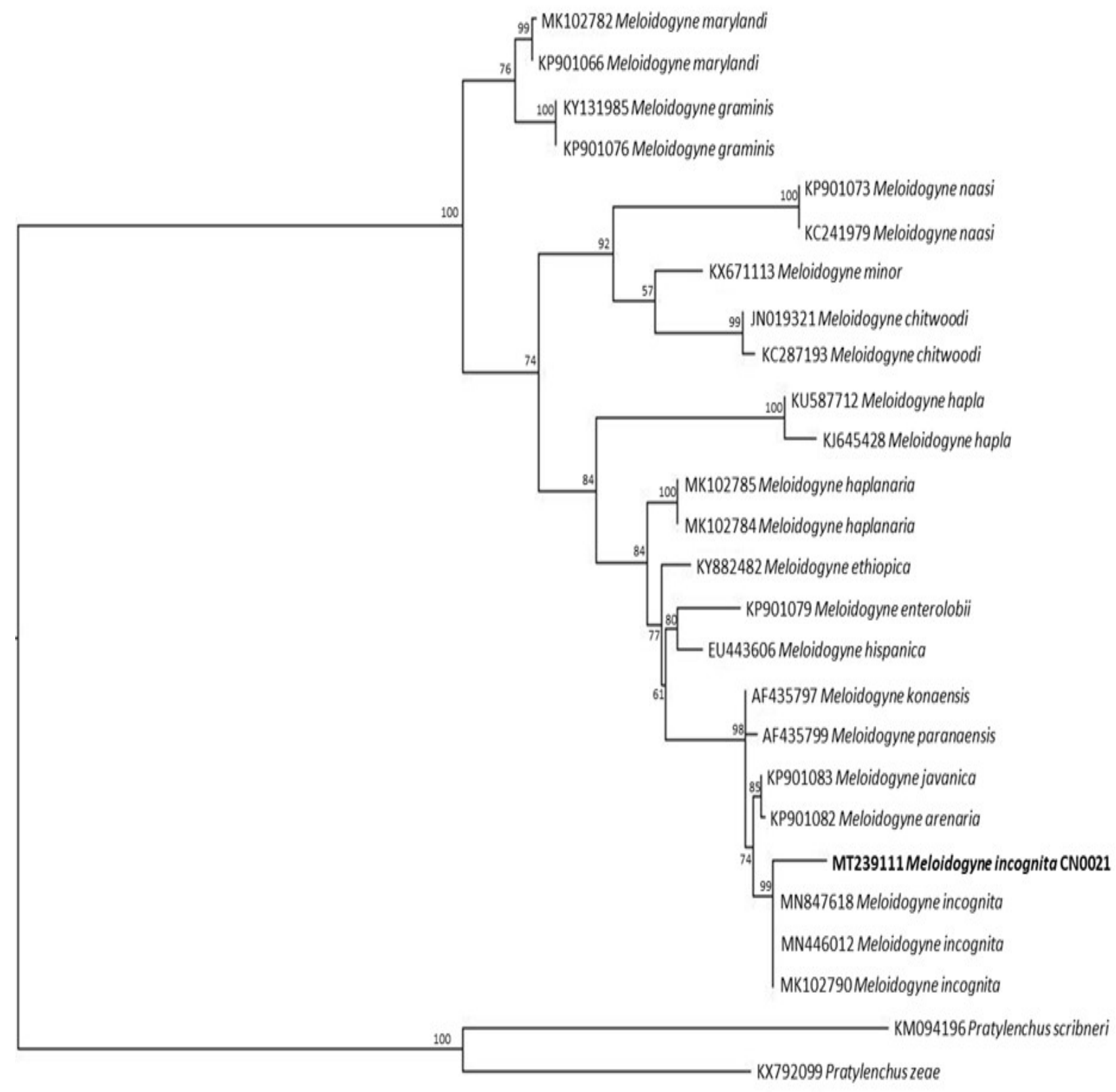


Figure 4. Phylogenetic relationship of Meloidogyne species based on the sequential alignment of the ITS rDNA region. The phylogenetic tree was estimated by Maximum Likelihood. Pratylenchus scribneri and $P$. zeae were used as outgroups.

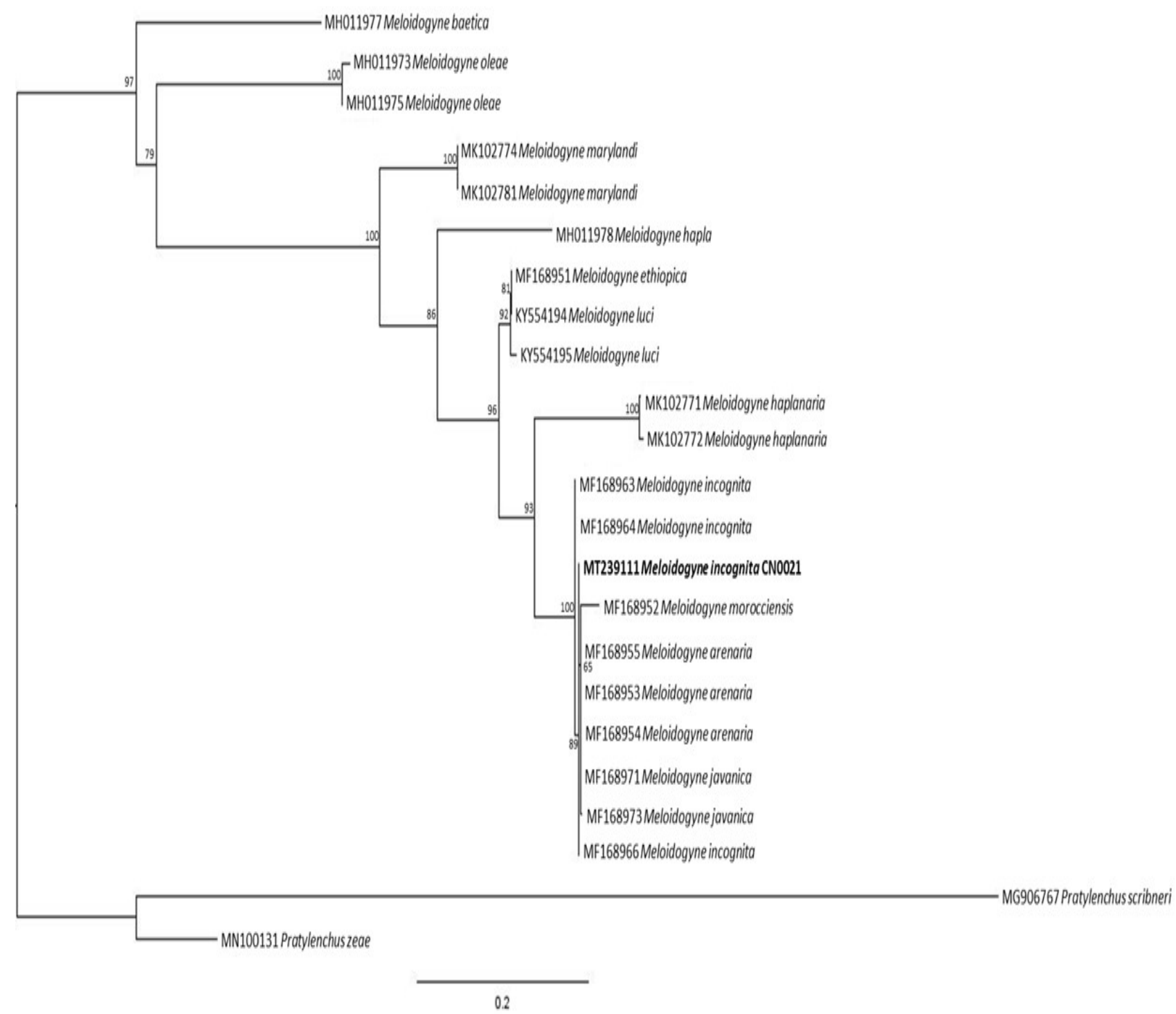

This is the first record of $M$. incognita in M. charantia in the state of Pernambuco, Brazil. However, the presence of this Meloidogyne species has been previously reported in "melão-de-SãoCaetano" in the states of Bahia, Ceará and Rio Grande do Norte (Freire and Ponte, 1976; Ponte, 1968; Ponte et al., 1976). This nematode has economic importance causing significant losses in the production of several crops (Ferraz and Brown, 2016) and, through the correct identification of the species, management practices to be adopted become more effective. Therefore, this work updates information on the parasitism of $M$. incognita in invasive plants present in agricultural areas in the state of Pernambuco.

\section{REFERENCES}

Carneiro, R.M.D.G.; Almeida, M.R.A. Técnica de eletroforese usada no estudo de enzimas dos nematoides das galhas para identificação de espécies. Nematologia Brasileira, 2001, 25, 35-44.

Coolen, W.A.; D'Herde, C.J. A method for the quantitative extraction of nematodes from plant tissue. State Agricultural and Entomology Research Station: Ghent, Bélgica, 1972; 77p.

Cordeiro, L.N; Athayde, A.C.R; Vilela, V.L.R.; Costa, J.G.M.; Silva, W.A.; Araujo, M.M.; Rodrigues, O.G. Efeito in vitro do extrato etanólico das folhas do melãode-São-Caetano (Momordicacharantia L.) sobre ovos 
e larvas de nematóides gastrintestinais de caprinos. Revista Brasileira de Plantas Medicinais, 2010, 12, 4, 421-426.

Coutinho, D.F.; Florêncio, J.C.; Aguiar, L.R.; Rodrigues, K.A.F.; Vilanova, C.M.; Borba, E.R.C. Estudo farmacobotânico das folhas de Momordica charantia $L$. (Cucurbitaceae). Visão Acadêmica, 2009, 10, 1, 7-17.

De Ley, P.; Felix, M.A.; Frisse, L.M.; Nadler, S.A.; Sternberg, P.W.; Thomas, W.K. Molecular and morphological characterization of two reproductively isolated species with mirror-image anatomy (Nematoda: Cephalobidae). Nematology, 1999, 1, 6, 591-612.

Ferraz, L.C.C.B.; Brown, D.J.F.Nematologia de plantas: fundamentos e importância. Norma Editora: Manaus, 2016; 251p.

Freire, F.C.O.; Ponte, J.J. Nematoides das galhas, Me1oidogyne spp., associados ao parasitismo de plantas no Estado da Bahia. Boletim Cearense de Agronomia, 1976, 17, 47-55.

Jones, J.T.; Haegeman, A.; Danchin, E.G.J.; Gaur, H.S.; Helder, J.; Jones, M.G.K.; Kikuchi, T.; Manzanilla-López, R.; Palomares-Rius, J.E.; Wesemael, W.M.L.; Perry, R.N. Top 10 plant $\square$ parasitic nematodes in molecular plant pathology. Molecular Plant Pathology, 2013, 14, 9, 946-961.
Moens, M.; Perry, R.N.; Starr, J.L. Meloidogyne species - a Diverse Group of Novel and Important Plant Parasites. In: Root-knot nematodes; Perry, R.N.; Moens, M.; Starr, J.L., Eds.; CABI: Wallingford, Inglaterra, 2009; pp. 1-18.

Ponte, J.J. Subsídios ao conhecimento de plantas hospedeiras e ao controle dos nematóides das galhas, Meloidogyne spp., no Estado do Ceara. Boletim Cearense de Agronomia,1968, 9, 1-26.

Ponte, J.J.; Fernandes, E.R.; Silva, A. T. Plantas hospedeiras de Meloidogyne no Estado do Rio Grande do Norte. Sociedade Brasileira de Nematologia, 1976, 2, 67-70.

Robinson, R.W.; Deckers-Walter, D.S. Cucurbits. Cab International: New York, Estados Unidos, 1997; 226p.

Stamatakis, A. RAxML version 8: a tool for phylogenetic analysis and post-analysis of large phylogenies. Bioinformatics, 2014, 30, 9, 1312-1313.

Taylor, A.L.; Netscher, C. An improved technique for preparing perineal patterns of Meloidogyne spp. Nematologica, 1974, 20, 2, 268-269.

Vrain, T.C.; Wakarchuk, D.A.; Levesque, A.C.; Hamilton, R.I. Intraspecific rDNA restriction fragment length polymorphism in the Xiphinema americanum group. Fundamental \& Applied Nematology, 1992, 15, 6, 563-573. 